\title{
ANALISIS KESALAHAN EJAAN BAHASA INDONESIA DALAM MEDIA MASSA DARING (DETIKCOM)
}

\author{
Nana Triana Winata \\ Program Studi Pendidikan Bahasa dan Sastra Indonesia, FKIP, Unwir, Indramayu \\ pos-el: nanawinata26@gmail.com
}

\begin{abstract}
ABSTRAK
Pada penelitian ini menganalisis kesalahan ejaan bahasa Indonesia yang digunakan oleh media massa daring Detikcom edisi terbit tanggal 6 dan 8 September 2019. Data yang diambil dalam penelitian ini ada tujuh berita yang terbit pada tangga 6 dan 8 September 2019 pada pukul $(19.19 ; 19.33 ; 21.00 ; 21.16 ; 13.30 ; 15.45 ; 19.19)$. Tujuan dalam penelitian ini adalah (1) mengetahui jenis ejaan yang salah dalam penulisan berita daring Detikcom edisi terbit tanggal 6 dan 8 September 2019 pada pukul (19.19; 19.33; 21.00; 21.16; 13.30; 15.45; 19.19); dan (2) menganalisis kesalahan ejaan bahasa Indonesia pada media massa daring Detikcom edisi terbit tanggal 6 dan 8 September 2019 pada pukul (19.19; 19.33; 21.00; 21.16; 13.30; 15.45; 19.19).

Penelitian ini menggunakan penelitian kualitatif karena pada penelitian ini mencari kesalahan ejaan bahasa Indonesia baik itu dari penggunaan huruf (huruf miring), kata (kata konjungsi), atau penggunaan tanda baca pada media massa daring. Bogdan dan Taylor dalam Moleong (2010:4) mengemukakan bahwa penelitian kualitatif adalah prosedur penelitian yang menghasilkan data deskriptif berupa kata-kata tertulis atau lisan dari orang-orang dan prilaku yang dapat diamati.

Kesalahan ejaan bahasa Indonesia yang digunakan oleh media massa daring Detikcom yang diterbitkan pada tanggal 6 dan 8 September 2019 pukul $(19.19 ; 19.33 ; 21.00 ; 21.16$; $13.30 ; 15.45 ; 19.19)$ sebagian besar terdapat pada huruf miring penamaan istilah bahasa asing.

Jenis kesalahan yang ditemukan pada edisi terbitan di atas adalah (1) kesalahan penggunaan huruf miring; (2) kesalahan penggunaan tanda baca; (3) kesalahan pengguanaan gabungan kata; dan (4) kesalahan penggunaan angka dan bilangan.

Kesalahan ejaan bahasa Indonesia di media massa daring Detikcom dalam bentuk pedoman penulisan huruf, kata, dan tanda baca.
\end{abstract}




\section{PENDAHULUAN}

Bahasa Indonesia adalah salah satu alat komunikasi yang digunakan oleh masyarakat Indonesia. Bahasa Indonesia menjadi bahasa yang digunakan dalam jurnalistik di Indonesia. Semua bidang jurnalistik baik itu dari media cetak, televise, atau media massa daring menggunakan bahasa Indonesia. Hal tersebut telah di atur oleh Undang-Undang No. 40 Tahun 1999 tentang pers nasional, ada lima fungsi dasar pers, yaitu sebagai media informasi, pendidikan, hiburan, kontrol sosial, dan lembaga ekonomi.

\section{Berdasarkan Undang-undang}

tersebut media massa sangat berperan penting khususnya dalam pelaksanaan pembinaan dan pengembangan bahasa Indonesia. Jika seluruh media massa (media massa cetak, televisi, atau media daring) telah menggunakan bahasa Indonesia sesuai dengan PUEBI (Pedoman Umum Ejaan Bahasa Indonesia), maka salah satu peran pers sesuai dengan Undang-undang No. 40 tahun 1999 yaitu sebagai pendidikan, dalam arti memberikan informasi pendidikan tentang penggunaan ejaan bahasa Indonesia sesuai dengan PUEBI.

Perkembangan teknolgi yang semakin pesat, dapat memudahkan semua masyarakat mendapatkan informasi khususnya dengan fasilitas internet. Pers yang ada di Indonesia pun berlomba-lomba membuat sebuah aplikasi daring yang dapat ditanam disemua gawai yang berbasis android ata IOS.

Masih banyak media massa daring yang kurang memperhatikan ejaan bahasa Indonesia. Tetapi ada pula media massa yang sangat memperhatikan ejaan bahasa Indonesia sesuai dengan PUEBI yang berlaku. Media massa daring Detikcom adalah salah satu media massa daring yang banyak ditanam pada gawai setiap orang. Setiap beberapa menit Detikcom selalu memperbarui informasi tentang semua berita yang terjadi di Indonesia.

Kesalahan penggunaan ejaan bahasa Indonesia yang sering terjadi pada penulisan berita yang dimuat oleh Detikcom relatif pada kesalahan penggunaan huruf miring ketika menggunakan istilah asing. Salah satu contoh kesalahan penggunaan cetak miring ditemukan pada Detikcom terbitan (Jumat, 6 September 2019 pukul 19:19 WIB) dengan judul berita "Sempat Jadi Pengamen Jalanan Noviana Akhirnya Bergelar Sarjana" yaitu pada "cleaning service". Selain itu, masih dalam tulisan berita yang sama tidak menggunakan tanda hubung (-) dalam penulisan "S1 dan S2".

Selain terjadi kesalahan dalam penggunaan huruf dan tanda baca, kesalahan yang ditemukan pada terbitan 
(Jumat, 6 September 2019 pukul 19:33) dengan judul berita "Harga Tanah Kawasan Industri RI Tinggi, Investor Berpaling ke Vietnam" yaitu kesalahan penggunaan kata bilangan "33” pada paragraf kedua. Selain kesalahan penggunaan kata bilangan, terjadi kesalahan penggunaan konjungsi "sehingga".

Fenomena kesalahan berbahasa tidak hanya terjadi pada media massa daring. Hampir semua media massa terjadi kesalahan dalam penggunaan ejaan bahasa Indonesia. Media massa adalah salah satu media penghubung ke masyarakat dalam pelaksanaan pembinaan dan pengembangan bahasa Indonesia.

Berdasarkan kesalahan ejaan bahasa Indonesia yang telah dipaparkan di atas, maka dapat dirumuskan sebagai berikut, (1) jenis ejaan apa saja yang salah dalam penulisan berita daring Detikcom edisi terbit tanggal 6 dan 8 September 2019 pada pukul $(19.19 ; 19.33 ; 21.00 ; 21.16 ; 13.30$; 15.45; 19.19)?; (2) bagaimana kesalahan ejaan bahasa Indonesia pada media massa daring Detikcom edisi terbit tanggal 6 dan 8 September 2019 pada pukul (19.19; 19.33; $21.00 ; 21.16 ; 13.30 ; 15.45 ; 19.19)$ ?

\section{METODOLOGI PENELITIAN}

Penelitian ini menggunakan penelitian kualitatif karena pada penelitian ini mencari kesalahan ejaan bahasa
Indonesia baik itu dari penggunaan huruf (huruf miring), kata (kata konjungsi), atau penggunaan tanda baca pada media massa daring. Bogdan dan Taylor dalam Moleong (2010:4) mengemukakan bahwa penelitian kualitatif adalah prosedur penelitian yang menghasilkan data deskriptif berupa katakata tertulis atau lisan dari orang-orang dan prilaku yang dapat diamati.

\section{HASIL DAN PEMBAHASAN}

Berdasarkan data penelitian dari media massa daring Detikcom, yang terbit pada 6 September 2019 pukul 19:19 WIB dengan judul berita "Sempat Menjadi Pengamen Jalanan Noviana Akhirnya Bergelar Sarjana". Pada berita tersebut terjadi kesalahan ejaan bahasa Indonesia, kesalahan itu meliputi penggunaan huruf miring pada istilah bahasa asing. Selain itu, Kesalahan pada penggunaan tanda baca (-). Data selanjutnya yang terbit pada 6 September 2019 pukul 19:33 WIB dengan judul berita "Harga Tanah Kawasan Industri RI Tinggi, Investor berpaling ke Vietnam". Pada berita ini terjadi kesalahan ejaan bahasa Indonesia dari kata (kata bilangan), konjungsi, huruf (huruf miring).

Pada terbitan 6 September 2019 pukul 21:00 WIB yang berjudul "Daftar Terkini Fintech Abal-abal hingga Gadai Ilegal, Hati-hati!”. Pada berita tersebut terjadi kesalahan ejaan bahasa Indonesia 
penggunaan huruf (huruf miring) yaitu istilah bahasa asing yang sebetulnya dapat diganti dengan menggunakan padanan kata dalam bahasa Indonesia.

Data berita pada terbitan 6 September 2019 pukul 21:16 WIB dengan judul "Kecanduan Main PUBG, Remaja ini Kena Serangan Stroke" dalam penulisan berita tersebut terdapat kesalahan ejaan bahasa Indonesia berupa penggunaan huruf (huruf miring), kesalahan penggunaan kata “jam” yang berbeda makna dengan "pukul” yang menunjukkan waktu.

Berita pada terbitan 8 September 2019 pukul 13.30 WIB dengan judul "Tak Merokok Dapat Keringanan Bayar Iuaran BPJS, Dokter Paru: Gimana Kontrolnya?". Terjadi kesalahan ejaan bahasa Indonesia gabungan kata diparagraf pertama, kesalahan penggunaan tanda baca titik (.) yang digunakan dalam singkatan gelar.

Berita pada terbitan 8 September 2019 pukul 15.45 WIB yang berjudul "Soetta Diklaim Bandara RI Pertama yang Sediakan Transportasi Online”. Pada berita ini terdapat kesalahan ejaan bahasa Indonesia yaitu penggunaan huruf miring yang tidak digunakan ketika menggunakan kata asing, ketika kata asing ini yang memiliki padanan kata bahasa Indonesia seharusnya kata asing tersebut diganti menjadi padanan kata bahasa Indonesia.

Berita pada terbitan 8 September
2019 pukul 17:19 WIB yang berjudul Parlemen Dinilai Hanya untuk Penuhi Syarat”. Kesalahan ejaan bahasa Indonesia pada berita ini adalah penggunaan tanda baca koma (,).

\section{Jenis Ejaan yang Salah}

\section{Huruf miring}

Beberapa fungsi dari huruf miring adalah ketika penggunaan judul buku, majalah yang ada di daftar pustaka. Huruf miring dipakai ketika menggunakan kata asing, ungkapan bahasa daerah, istilahistilah bahasa asing/geografi/biologi.

Dari data yang diambil, kesalahan ejaan bahasa Indonesia yang digunakan oleh media massa daring Detikcom sebagian besar adalah penggunaan huruf miring dalam istilah atau kata asing.

Salah satu istilah asing yang digunakan pada berita di atas adalah istilah "cleaning service", istilah tersebut ditulis tidak cetak miring "cleaning service" dalam teks beritanya. Seharusnya istilah tersebut ditulis miring "cleaning service" karena termasuk dalam istilah bahasa asing (bahasa Inggris).

Hampir dalam setiap pemberitaan baik itu media cetak, televisi, atau media daring. Penggunaan istilah asing "online" hampir selalu digunakan. Istilah tersebut kini marak digunakan diberbagai pemberitaan mana pun. Seharusnya pengguanaan istilah asing "online" ditulis 
BAHTERA INDONESIA:

Jurnal Penelitian Pendidikan Bahasa dan Sastra Indonesia
ISSN 2541-3252

Vol. 4, No. 2, Sep. 2019 huruf miring "online" atau istilah tersebut diganti menjadi padanan kata dalam bahasa Indonesia yaitu "daring”. Penggunaan kata "daring' untuk istilah "online" harus sering digunakan oleh media massa guna membina bahasa Indonesia dikalangan masyarakat secara luas.

Penggunaa istilah asing "game" dalam teks berita seharusnya menggunakan huruf miring "game", karena kata tersebut termasuk dalam istilah bahasa asing (bahasa Inggris).

Kesalahan ejaan bahasa Indonesia dalam penulisan huruf miring pada istilah bahasa asing "stress", seharusnya menggunakan huruf miring "stress" atau cukup dengan menggunakan bahasa Indonesia sesuai dengan KBBI (Kamus Besar Bahasa Indonesia) "stres" yang artinya "gangguan atau kekacauan mental dan emosional yg disebabkan oleh factor luar; ketegangan.

Penggunaan istilah asing atau istilah nama penyakit "stroke", pada teks berita yang ditulis tidak menggunakan huruf miring, seharusnya kata stroke menggunakan huruf miring "stroke" karena kata tersebut termasuk dalam istilah bahasa medis atau istilah nama penyakit.

\section{Tanda Baca}

Beberapa pembaca masih mengacu penggunaan tanda baca pada EyD (Ejaan yang Disempurnakan), pada saat ini kita harus melupakan EyD karena telah diubah menjadi PUEBI (Pedoman Umum Ejaan Bahasa Indonesia). Ketika akan melihat aturan penggunaan tanda baca bahasa Indonesia harus merujuk pada PUEBI.

Dari data yang telah didapat kesalahan penggunakan tanda baca hubung (-) pada singkatan untuk Strata satu dan Strata dua pada tulisan diteks berita menggunakan (S1) dan (S2), jika menggunakan singkatan tersebut maka akan memiliki makna yang berbeda. Jika menulis menggunakan (S1) akan memiliki makna bahwa /S/ hanya ada satu huruf, yang berarti hanya bermakna "strata". Begitupun penulisan (S2) akan memiliki makna huruf /S/ ganda sama dengan penulisan seperti (SS). Seharusnya untuk kesalahan penulisan di atas menggunakan tanda baca hubung (-). Penulisan yang benar sesuai dengan PUEBI "strata satu" dan "strata dua" yaitu "S-1" dan "S-2".

Keslahan penggunakan tanda baca titik (.) untuk singkatan nama gelar atau pangkat pada nama orang. Contoh kesalahan yang ada pada data berita daring Detikcom (8/9/2019, pukul 13.30) adalah “dr Feni Fitriani Taufik, $\operatorname{SpP}(K)$ ". Penulisan singkatan nama gelar menurut PUEBI menggunakan tanda baca titik (.), sehingga penulisan yang benar adalah "dr. Feni Fitriani Taufik, Sp. P(K)”.

Masih dalam kesalahan penggunaan 
tanda baca titik (.) yang digunakan pada istilah jam dan menit. Kesalahan pada media massa daring tersebut adalah "jam 9 malam, pukul 3 atau 4 subuh". Penggunaan kata "jam" tidak tepat jika untuk menunjukkan waktu karena menurut KBBI jam artinya "(1) alat untuk mengukur waktu (seperti arloji, lonceng dinding); (2) waktu yang lamanya 1/24 hari (dari sehari semalam) sama dengan 60 menit atau 3.600 detik". Seharusnya ketika penggunaan ejaan bahasa Indonesia untuk menunjukkan waktu menggunakan tanda baca titik (.) seharusnya "pukul 21.00 atau pukul 09.00 malam; pukul 03.00 atau pukul 03.00 pagi; pukul 04.00 atau pukul 04.00 pagi”.

Berdasarkan data yang didapat kesalahan dalam penggunaan tanda baca koma terjadi pada penghubung antarkalimat “... oleh karena itu menurut saya ...". Seharusnya kata hubung antarkalimat menggunakan tanda baca koma (,), misalnya "oleh karena itu(,)"; "meskipun demikian(,)"; “dengan demikian(,)". Pada penggalan kalimat yang tercetak pada teks di atas tidak menggunakan tanda baca koma (,). Menurut PUEBI yang benar penggunaannya harus menggunakan tanda baca koma (,) menjadi “... oleh karena itu, menurut saya ...".

Dalam penggunaan kata hubung yang tidak tepat terdapat pada kalimat “... justru melirik Vietnam, Malaysia hingga Kamboja dan Thailand.”

Pada kalimat tersebut seharusnya menggunakan tanda baca koma (,) yang berfunsi untuk suatu perincian. Jadi kalimat tersebut berdasarkan PUEBI menggunakan tanda baca koma (,) menjadi kalimat “... justru melirik Vietnam, Malaysia, Kamboja, dan Thailand.”

\section{Gabungan Kata}

Terdapat kesalahan penulisan gabungan kata yang ada dalam teks berita daring “. . banyak ditentang oleh kalangan non perokok." Kata non- tidak bisa berdiri sendiri, kata tersebut harus digabung dengan kata lain yang mengikutinya. Jadi, penulisan yang benar adalah “... banyak ditentang oleh kalangan nonperokok."

\section{Angka dan Bilangan}

Kesalahan penggunaan ejaan bahasa Indonesia angka dan bilangan "33 perusahaan tersebut justru ..." Pada kalimat di atas terjadi kesalahan penggunaan angka di awal kalimat. Jika terdapat angka di awal kalimat harus diubah menjadi ejaan huruf. Jadi penulisan yang benar sesuai dengan PUEBI adalah "Tiga puluh tiga perusahaan tersebut justru ..."

\section{SIMPULAN}

Berdasarkan hasil analisis data di atas, kesalahan ejaan bahasa Indonesia yang digunakan oleh media massa daring Detikcom yang diterbitkan pada tanggal 6 dan 8 September 2019 pukul (19.19; 19.33; $21.00 ; \quad 21.16 ; \quad 13.30 ; \quad 15.45 ; \quad 19.19)$ 
BAHTERA INDONESIA:

Jurnal Penelitian Pendidikan Bahasa dan Sastra Indonesia
ISSN 2541-3252

Vol. 4, No. 2, Sep. 2019

sebagian besar terdapat pada huruf miring

penamaan istilah bahasa asing.

Jenis kesalahan yang ditemukan

pada edisi terbitan di atas adalah (1)

kesalahan penggunaan huruf miring; (2)

kesalahan penggunaan tanda baca; (3)

kesalahan pengguanaan gabungan kata;

dan (4) kesalahan penggunaan angka dan

bilangan.

Kesalahan ejaan bahasa Indonesia dalam media massa daring Detikcom dalam bentuk pedoman penulisan huruf, kata, dan tanda baca.

\section{DAFTAR PUSTAKA}

Alwasilah, A. Chaedar. 2011. Linguistik Suatu Pengantar. Bandung: Angkasa.

Alwi, H. dkk. 2003. Tata Bahasa Baku Bahasa Indonesia Edisi Ketiga. Jakarta: Balai Pustaka.

Apriani, Mia. 2016. Analisis Kesalahan Berbahasa Bidang Morfologi oleh Komunitas Jual-Beli Online di Daerah Mataram Nusa Tenggara Barat.Mataram: Skripsi FKIP Universitas Mataram.

Chaer, Abdul. 2009. Fonologi Bahasa Indonesia. Jakarta: PT Rineka Cipta.

Moloeng, L. J. 2010. Metodologi Penelitian Kualitatif. Bandung: Remaja Rosdakarya.

Ramlan, M. 1987. Morfologi Suatu Tinjauan Deskriptif. Yogyakarta: Gadjah Mada University Press.

Sugiarto, E. 2017. Kitab PUEBI Pedoman Umum Ejaan Bahasa Indonesia. Yogyakarta: Andi. 